\title{
IMPROVING ENERGY EFFICIENCY IN BUILDINGS USING MICROGRIDS
}

\author{
Mario Primorac \\ Josip Juraj Strossmayer University of Osijek, Faculty of Electrical Engineering, Expert Associate \\ Corresponding author: mprimorac@etfos.hr \\ Mario Šipoš \\ Croatian Armed Forces, Zagrebačka 2, 43000 Bjelovar, Croatia \\ Zvonimir Klaić \\ Josip Juraj Strossmayer University of Osijek, Faculty of Electrical Engineering in Osijek, Assistant \\ Professor
}

\begin{abstract}
Modern society has a growing need for the electricity. To protect the environment, future energy demand must be met with more environmentally friendly technologies, such as renewable energy sources. Because of its vast availability, solar radiation has been used for decades to generate electricity through photovoltaic systems (PV) for residential, educational, and commercial buildings. However, the growth of distributed generation (and renewable energy sources) across power systems in industrialized countries has created new challenges. Random renewable generation causes an imbalance between electricity production and consumption, so smart grids and microgrids may be solutions. In this article, we investigate improving the energy efficiency in the Faculty of Electrical Engineering building in Osijek by using a microgrid. To do so, we compared the total electricity consumption of the building and the production of a $10 \mathrm{kWp}$ photovoltaic power plant on that building. The improvement in energy efficiency of the building produced a maximum savings of up to $10 \%$ of the building's total electricity consumption.
\end{abstract}

Keywords: distributed generation; renewable energy sources; energy efficiency; microgrid; PV power plant

\section{POBOLJŠANJE ENERGETSKE UČINKOVITOSTI U ZGRADARSTVU POMOĆU MIKROMREŽA}

Sažetak: Moderno društvo ima sve veću potrebu za električnom energijom. Kako bi se zaštitio okoliš, buduća potražnja će morati biti pokrivena s više ekološki prihvatljivih tehnologija, poput obnovljivih izvora energije. Zbog svoje visoke dostupnosti, Sunčevo zračenje se već desetljećima koristi za proizvodnju električne energije putem fotonaponskih sustava (PV) na stambenim, obrazovnim ili poslovnim zgradama. Prodor distribuirane proizvodnje (i obnovljivih izvora energije) u elektroenergetske sustave industrijaliziranih zemalja stvara nove izazove. Nestalna proizvodnja obnovljivih izvora električne energije stvara neravnotežu između proizvodnje i potrošnje, a kao moguće rješenje općenito je prihvaćen koncept napredne mreže i mikromreže. Ovaj članak istražuje mogućnosti povećanja energetske učinkovitosti pomoću mikromreže u zgradi Elektrotehničkog fakulteta Osijek. Uspoređuje se ukupna potrošnja električne energije u zgradi Fakulteta s proizvodnjom od $10 \mathrm{kWp}$ fotonaponske elektrane ETFOS 1, koja se nalazi na krovu iste zgrade. Usporedba navedenih rezultata pokazala je poboljšanje energetske učinkovitosti zgrade u obliku maksimalne uštede, koja doseže i do $10 \%$ ukupne potrošnje.

Ključne riječi: distribuirana poizvodnja; obnovljivi izvori energije; energetska učinkovitost; mikromreža; fotonaponska elektrana 


\section{INTRODUCTION}

The expansion of distributed generation across the power systems in industrialized countries creates new challenges for all stakeholders. Random renewable generation causes the an imbalance between electricity production and consumption, and at the same time, power consumption continues to increase, while consumer's power loads are becoming more complex. Because of these issues, it is necessary to invest in the distribution network, where conventional distribution network changes their structure from passive to active. According to [1], the active network in which the processes of energy generation, distribution, and use are executed in a controllable way, forms an electrical power microgrid.

In distributed generation (DG), small electricity generators are connected directly to the distribution network, or at the customer side, with a rated power typically less than $10 \mathrm{MW}[2,3]$. Photovoltaic power plants belong to a group of renewable-based DG, and production of photovoltaic energy is currently undergoing explosive growth, both in developed and developing countries. Almost every definition of microgrid includes PV generation as a part of the supply side of the microgrid.

In this paper, we present measurements from a grid-connected PV system and the total electricity consumption of the building of the Faculty of Electrical Engineering in Osijek. The measurement period was one year: from June 2014 to May 2015. The paper reviews various concepts and applications of microgrids, emphasizing microgrids in building management systems. Photovoltaic power plant is one of the the most common part of the microgrids, so we also describe the basics of PV technology. Finally, we give graphics and tables on the measurements and the calculated energy savings.

\section{MICROGRIDS}

Many authors have studied various the concepts and applications of microgrids.

Kroposki at al. defines microgrids as systems with at least one distributed energy resource and associated loads and can form intentional islands in the electrical distribution systems [4]. The basic technologies necessary for operating a microgrid include the DG, distributed storage (DS), interconnection switches, and control systems, as shown in Figure 1.

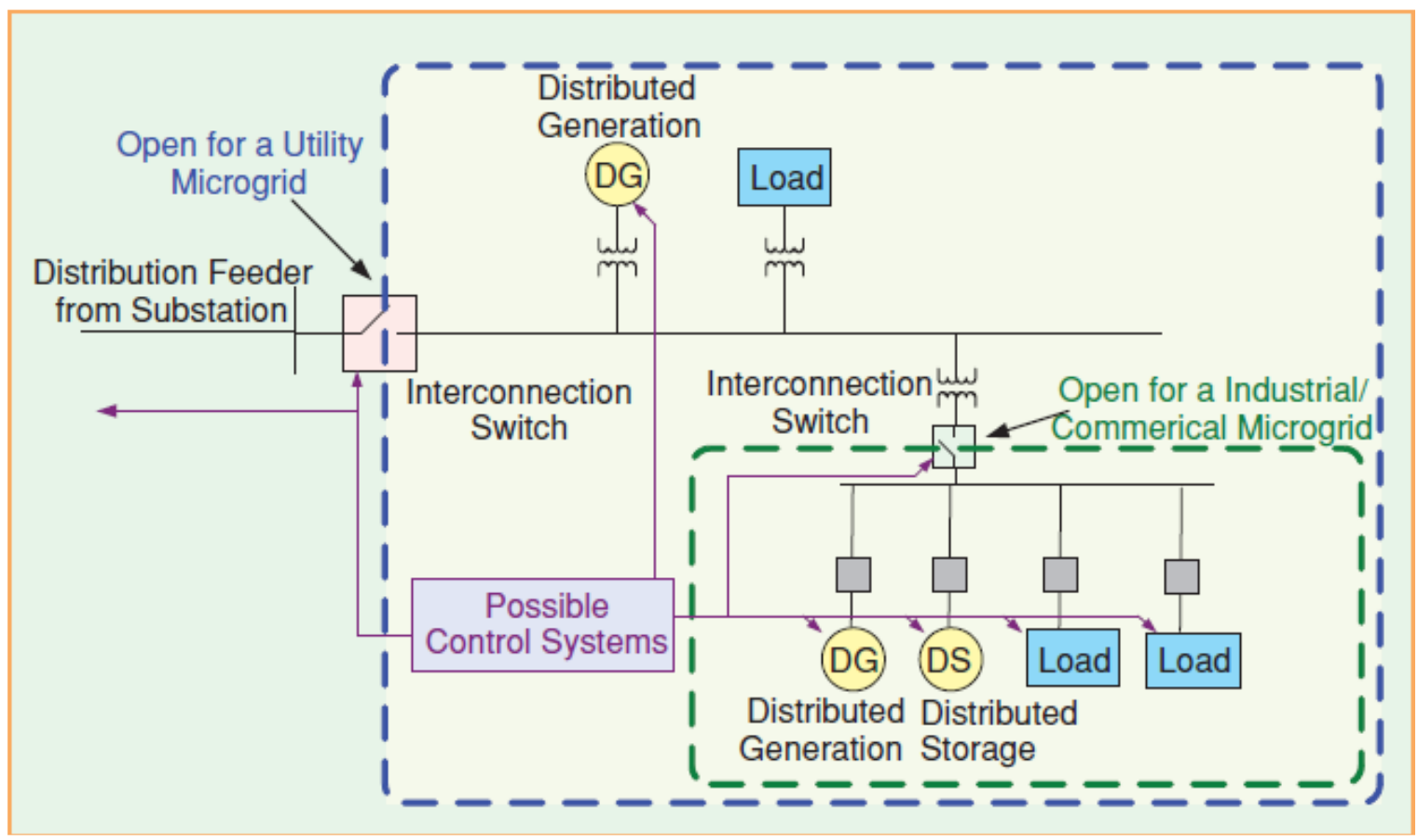

Figure 1 Microgrids and components [4] 
According to Liu et al. [5], microgrids may be a power system that can addresses the issues with renewable energy technologies (RETs) accompanying the growing deployment of distributed energy resources (DER), especially small-scale combined heat and power (CHP) and small-scale renewable energy sources (RESs). Liu et al. introduced the RET expected to be applied in the microgrid system depending on the RES: microturbines, fuel cells, photovoltaic cells, solar thermal arrays, and wind turbines, as well as the storage, load control, power and voltage regulation and heat recovery units. They concluded that developing a microgrid based on distributed generation together with renewables could greatly affect how rural electrification is approached, especially in developing countries.

Katiraei and Iravani defined the microgrid as a cluster of distributed generation (DG) units and loads, serviced by a distribution system. The microgrid can operate in one of three ways: the grid-connected mode, the islanded (autonomous) mode, and ride-through between the two modes [6]. These authors addressed real and reactive power management strategies (PMS) of electronically interfaced DG units in the context of a multiple-DG microgrid system and studied how the electronically interfaced DG units and the adopted PMS affected the dynamic behavior of the microgrid.

\subsection{Microgrid and Building Management System}

In industrialized countries, nearly $40 \%$ of the total energy is consumed by buildings, and $68 \%$ of this energy is electrical $[7,8,9]$. A substantial amount of building energy consumption $(20 \%-30 \%$, according to recent research) can be saved without changing the building energy supply system. Those energy savings are possible through efficient building energy operation and management. According to various authors [7, 10-13], microgrids are desirable for improving the efficiency of buildings' energy consumption.

According to Guan et al. [7], a typical microgrid for buildings integrates the operation of electrical and thermal energy supply and demand, as shown in Figure 2 . The supply side usually consists of energy sources from the distribution grid and autonomous power generators (fuel cells, combined heat and power (CHP) systems, and renewable energy resources such as PV solar cells and wind powers) as well as energy storage devices (batteries and water tanks). The main objective of a microgrid is to coordinate and optimize the operation of all existing energy sources and loads.

Marnay et al. [14] produced an optimization model for electrical and thermal storage options in commercial buildings. For this optimization, they used Berkeley Lab's Distributed Energy Resources Customer Adoption Model (DER-CAM). DER-CAM chose annual energy bill minimizing systems in a fully technology-neutral manner, reporting an example for a hypothetical San Francisco hotel. Their results showed that using better building energy analysis and design tools can accelerate the adoption of CHP, facilitating the deployment of microgrids.

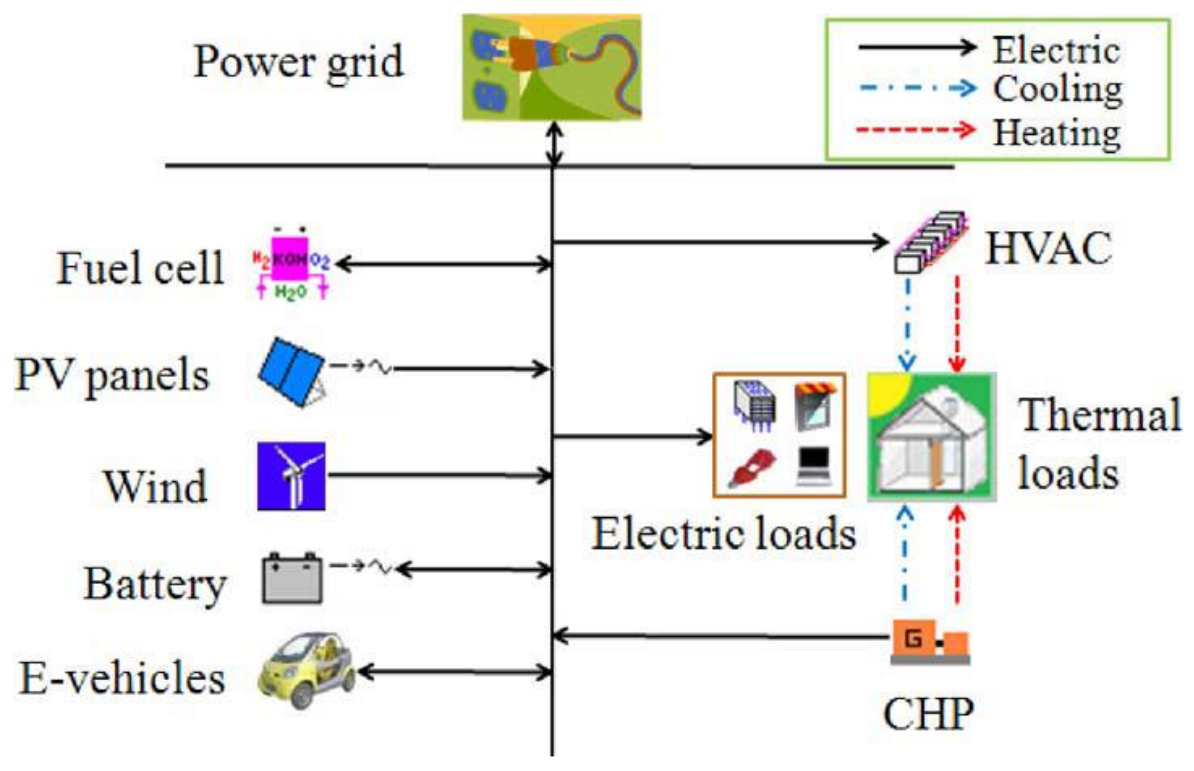

Figure 2 Energy system of buildings 


\section{PV TECNOLOGY}

Photovoltaic modules convert solar radiation into the electrical power. One benefit of PV systems is their long lifetime [15]. A solar cell is the smallest unit of a PV generator, as shown in Figure 3.

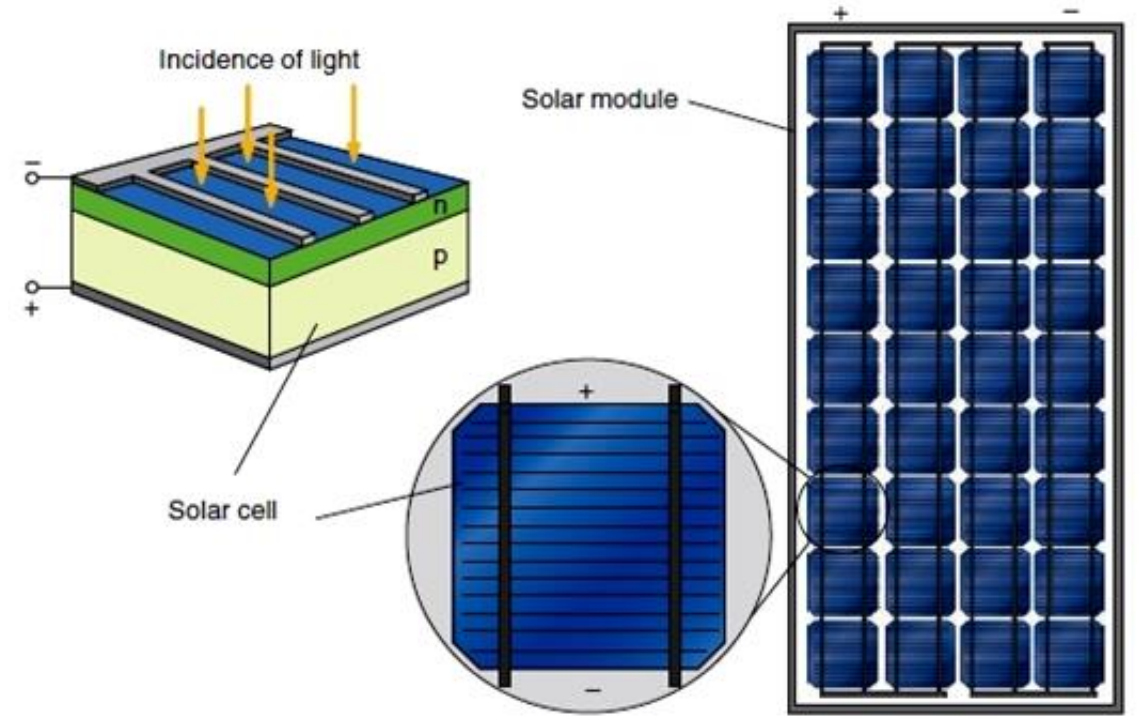

Figure 3 A solar cell and solar module [16]

Crystalline silicon (SI) is the most commonly used material in PV cells. Semiconductors have few free electrons but, when they are exposed to sunlight, can release electrons from their positions in the atomic structure. Release of electrons makes positively charged holes. The separation layer between phosphorus ( $\mathrm{n}$ type) and boron (p-type) separates the electrons from holes. Exposed by sunlight, the silicon layer acts as a battery with positive and negative potentials. For crystalline silicon, this voltage is around $0.5 \mathrm{~V}$ [17]. The solar cell produces electricity when it absorbs solar radiation. Influenced by the photovoltaic effect (ability to convert sunlight to electricity), electromotive force (voltage) appears at ends of solar cell. Thus, the solar cell becomes a semiconductor diode, and the $p-n$ junction conducts current only in one direction. When the solar cell is exposed to light, the absorbed photons produce electron-hole pairs. The p-side contact becomes positive, and the n-side contact becomes negative. The electrons move to the $n$-side, and the holes move to the $p$-side. When the contacts are connected to external loads, the solar cell generates electricity, as shown in Figure $4[17,18]$. $[16,19]$.

An inverter converted direct current (DC) into alternating current (AC), then the $A C$ is injected into the grid

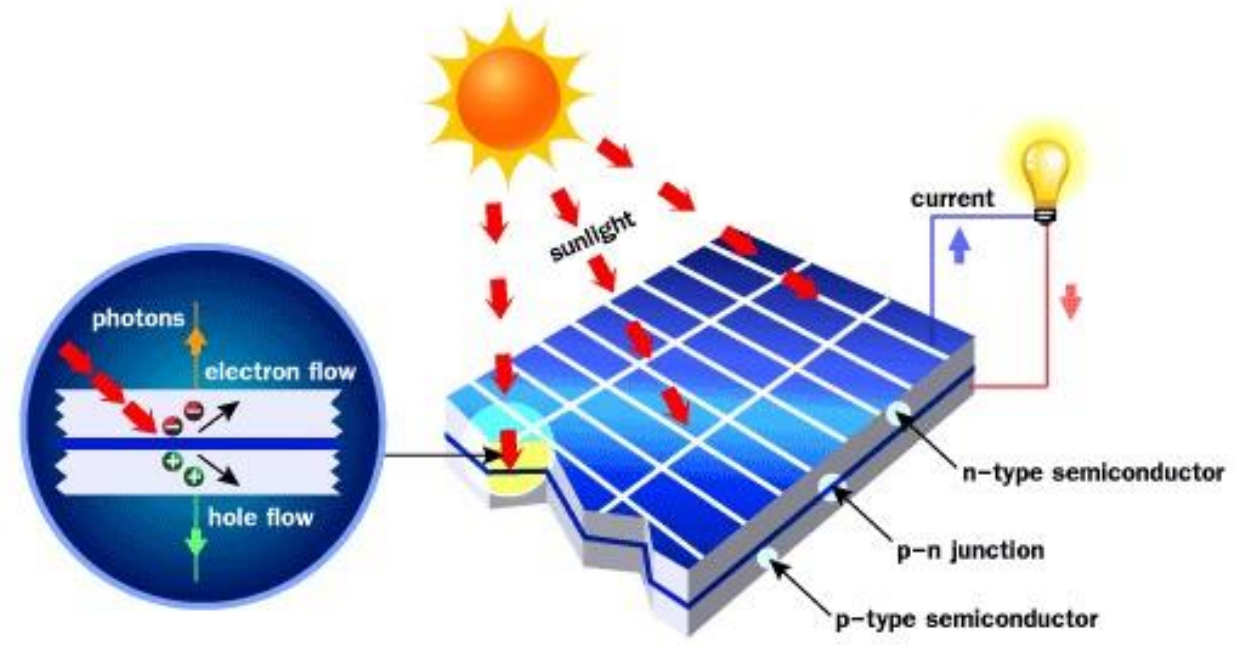

Figure 4 The solar cell as a source of electricity [20] 
The solar module consists of many solar cells connected in series, producing a usable voltage, and multiple solar modules can be connected in series to make a photovoltaic plant. Grid-connected PV are mostly installed in existing buildings (residential, office, and industrial), producing a peak power from $200 \mathrm{Wp}$ to $5 \mathrm{kWp}$. In most cases, electric power generated by a PV system is first consumed by the building into which the PV system is integrated, then the surplus is fed into the utility grid [17].

\section{CALCULATION OF ENERGY SAVING IN FACULTY BUILDING USING MICROGRID}

To investigate possible improvements in energy efficiency in the faculty building, we measured the production of a $10 \mathrm{kWp}$ photovoltaic power plant and the total electricity consumption, as shown in Figure 5 [21].

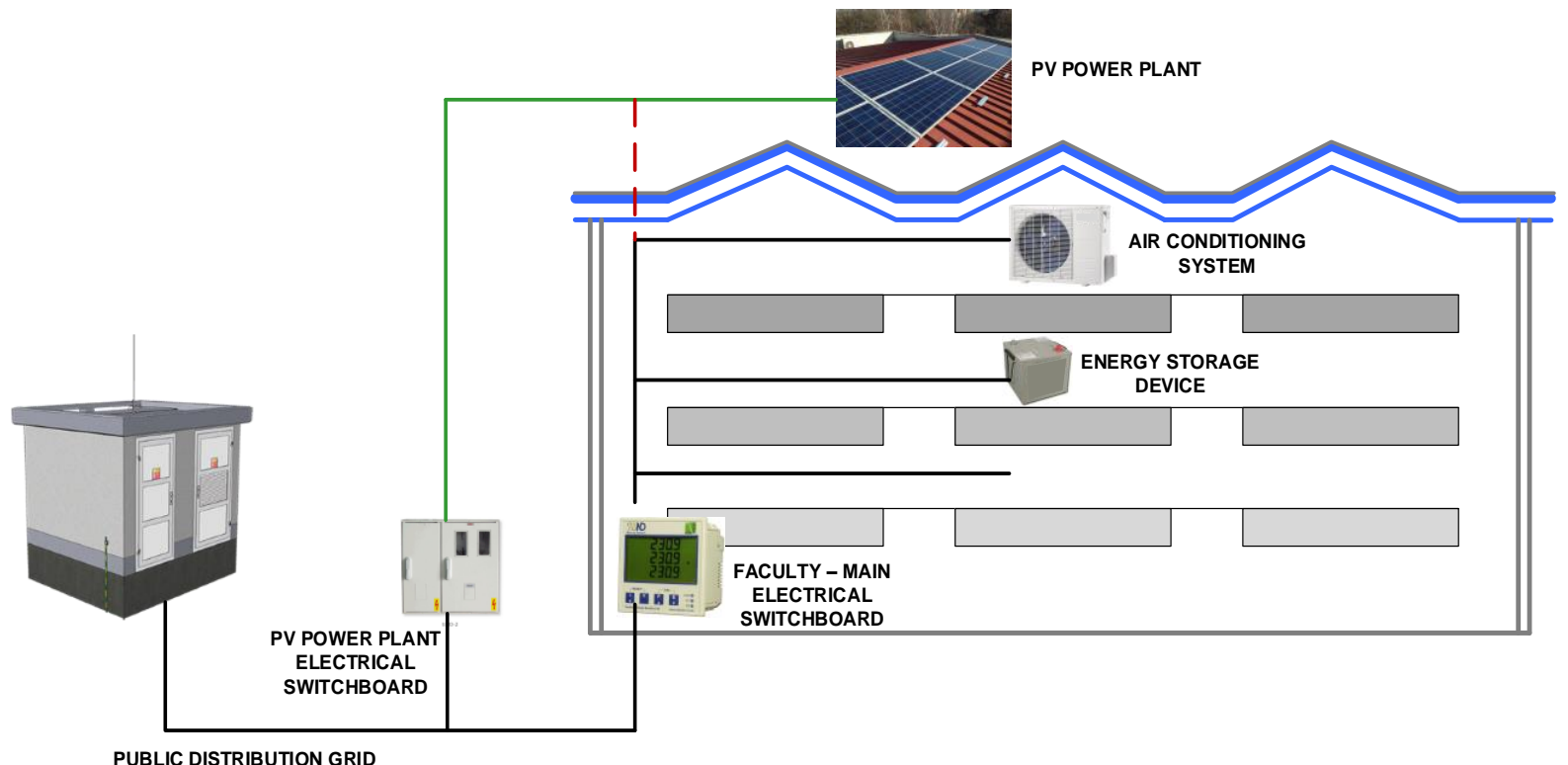

Figure 5. The main building of the Faculty of Electrical Engineering

The photovoltaic power plant ETFOS 1 is located at the Faculty of Electrical Engineering building as part of the Laboratory for Renewable Energy Sources. The lab consisted of two parts, internal and external.

The inside of the laboratory contained the measuring equipment, while the outside contained the photovoltaic power plant ETFOS 1, as shown in Figure 6.

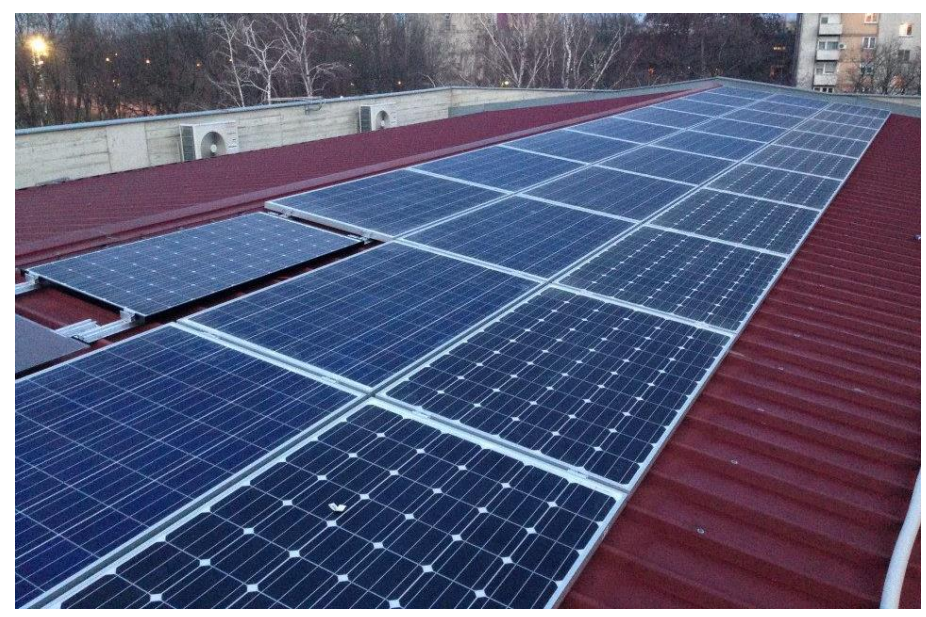

Figure 6 ETFOS 1 PV power plants 
The photovoltaic power plant ETFOS 1 has a total installed power of $10 \mathrm{kWp}$ and consists of two strings. The first string has 20 monocrystalline modules connected in series, while the other set has the same number of polycrystalline modules. The modules have a maximum power of $250 \mathrm{Wp}$ for both technologies. Modules are connected to the public distribution network via three-phase power inverter, as shown in Figure 7 [21]. Besides the modules on the roof, there is equipment that measures the solar radiation and weather conditions (temperatures, relative humidity, and wind speed).

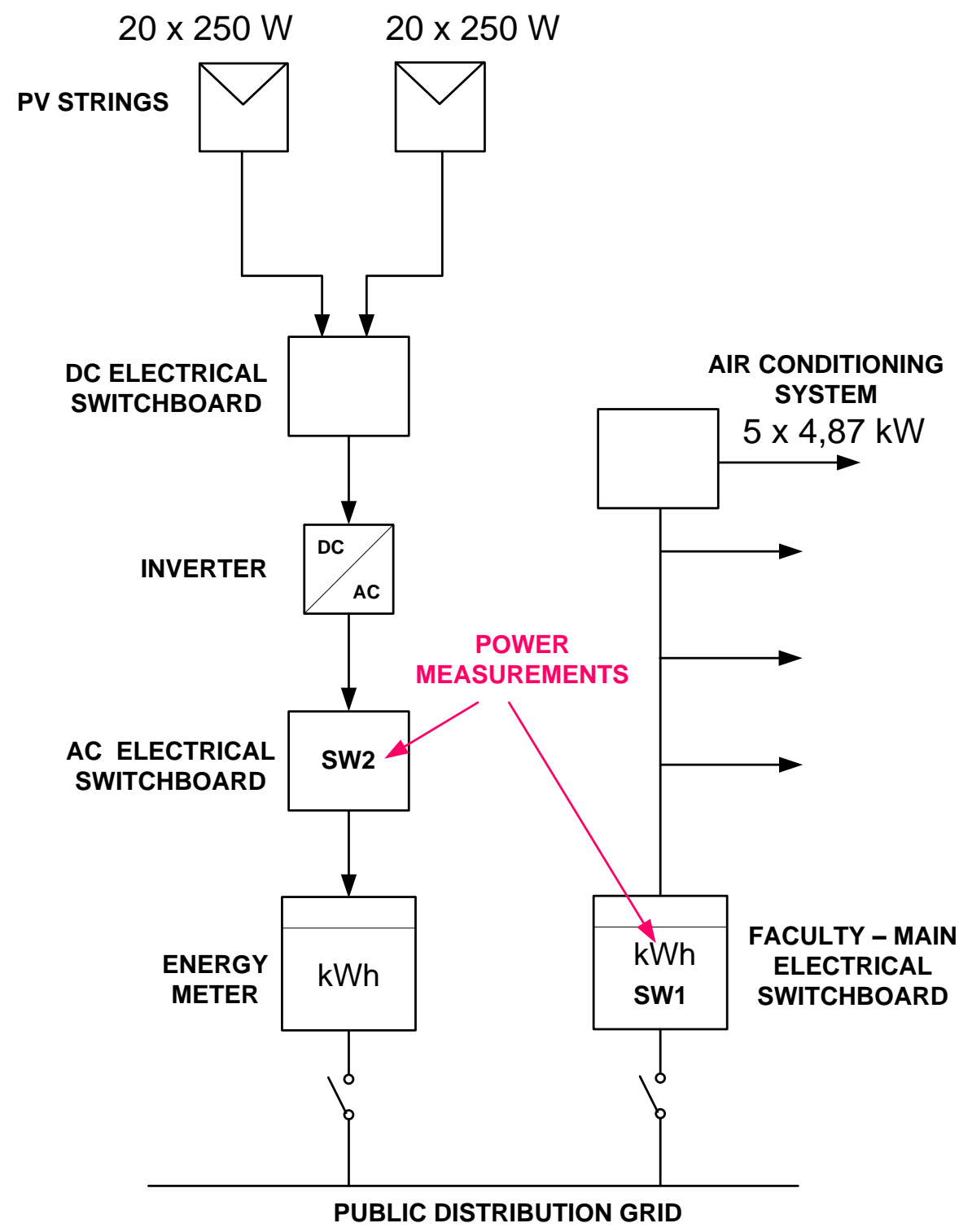

Figure 7 Connection scheme of the PV power plant and measurement sites

At present, the PV power plant ETFOS 1 will be connected directly to the future microgrid, and all calculations were performed for the direct connection. The energy savings were calculated based on the results of measurements over one year: from June 1st, 2014 to May 31st, 2015. Table 1 shows the total consumption of the faculty building $\left(E_{\mathrm{TOT}}\right)$ and the production of the ETFOS 1 photovoltaic power plant ( $\left.E_{\mathrm{ETFOS} 1}\right)$, for every month of the year. The right column of Table 1 and Figure 8 shows the percentage of the PV plant production as a proportion of the the faculty building's consumption. 
Table 1 Total consumption of the Faculty and Production of photovoltaic power plant

\begin{tabular}{|c|c|c|c|}
\hline \multirow{3}{*}{ Month } & $\begin{array}{l}\text { Consumption of the } \\
\text { faculty building }\end{array}$ & $\begin{array}{l}\text { Production of photovoltaic power } \\
\text { plant ETFOS } 1\end{array}$ & $\begin{array}{l}\text { The percentage of production in } \\
\text { relation to the consumption }\end{array}$ \\
\hline & $E_{\text {TOT }}$ & $E_{\mathrm{ETFOS} 1}$ & $E_{\mathrm{S}}$ \\
\hline & [kWh] & {$[\mathrm{kWh}]$} & {$[\%]$} \\
\hline Jun. 2014 & 20252 & 1560 & 7.70 \\
\hline Jul. 2014 & 18508 & 1552 & 8.39 \\
\hline Aug. 2014 & 13597 & 1360 & 10.00 \\
\hline Sep. 2014 & 19161 & 835 & 4.36 \\
\hline Oct.2014 & 20919 & 653 & 3.12 \\
\hline Nov.2014 & 20407 & 329 & 1.61 \\
\hline Dec. 2014 & 19425 & 138 & 0.71 \\
\hline Jan. 2015 & 19752 & 139 & 0.70 \\
\hline Feb. 2015 & 18531 & 369 & 1.99 \\
\hline Mar .2015 & 19967 & 932 & 4.67 \\
\hline Apr. 2015 & 18814 & 1299 & 6.90 \\
\hline May. 2015 & 18204 & 1372 & 7.54 \\
\hline
\end{tabular}

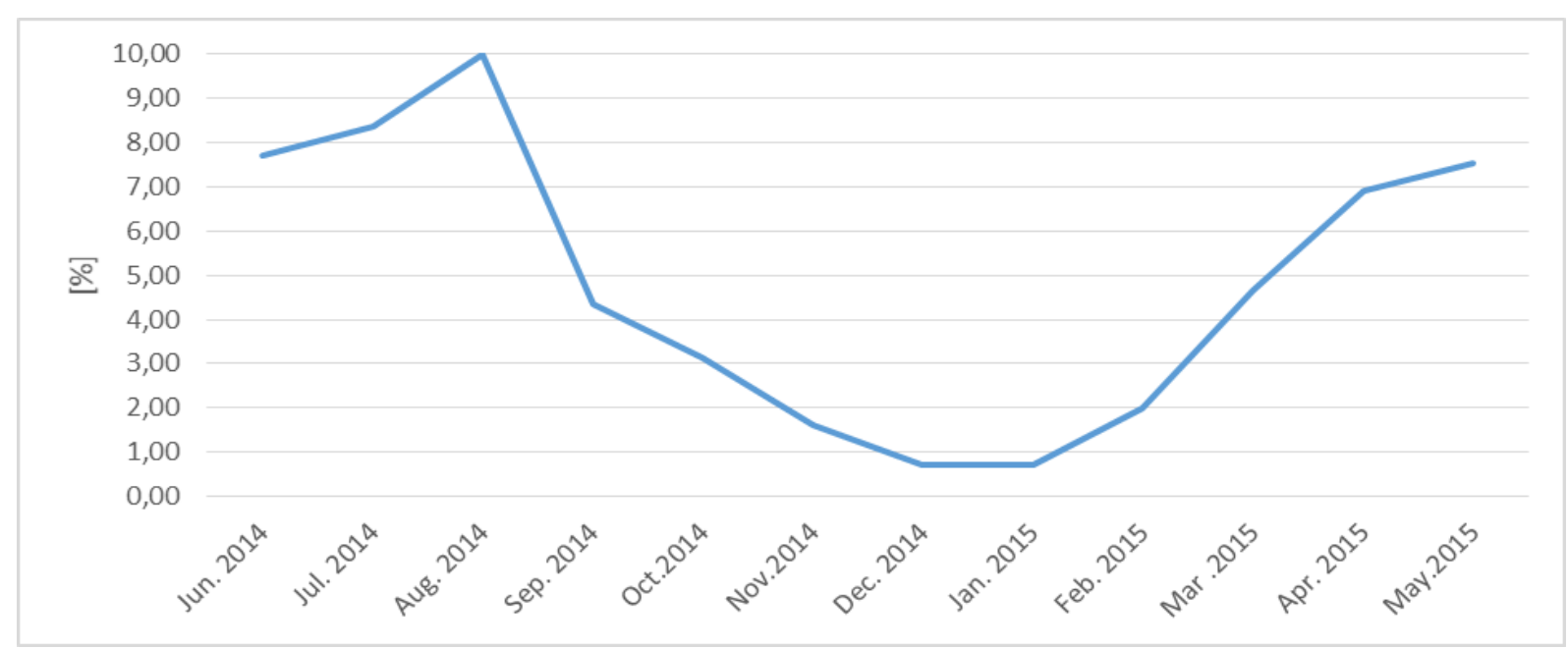

Figure 8 Energy production as a percentage of consumption

In this work, we compared the electricity bills for the faculty building to the produced energy. Besides electricity consumption, the bill also has a network tariff, which is also charged per kWh.

These results show that the PV power plant improved the energy saving of the faculty building. As expected, the maximum savings were achieved in the summer months, specifically in August: up to $10 \%$ of the total consumption. In the summer, the PV plant produces the most energy, and the students and most employees of the faculty building are on holiday, so the building consumes minimal energy, as shown in Figure 9. 


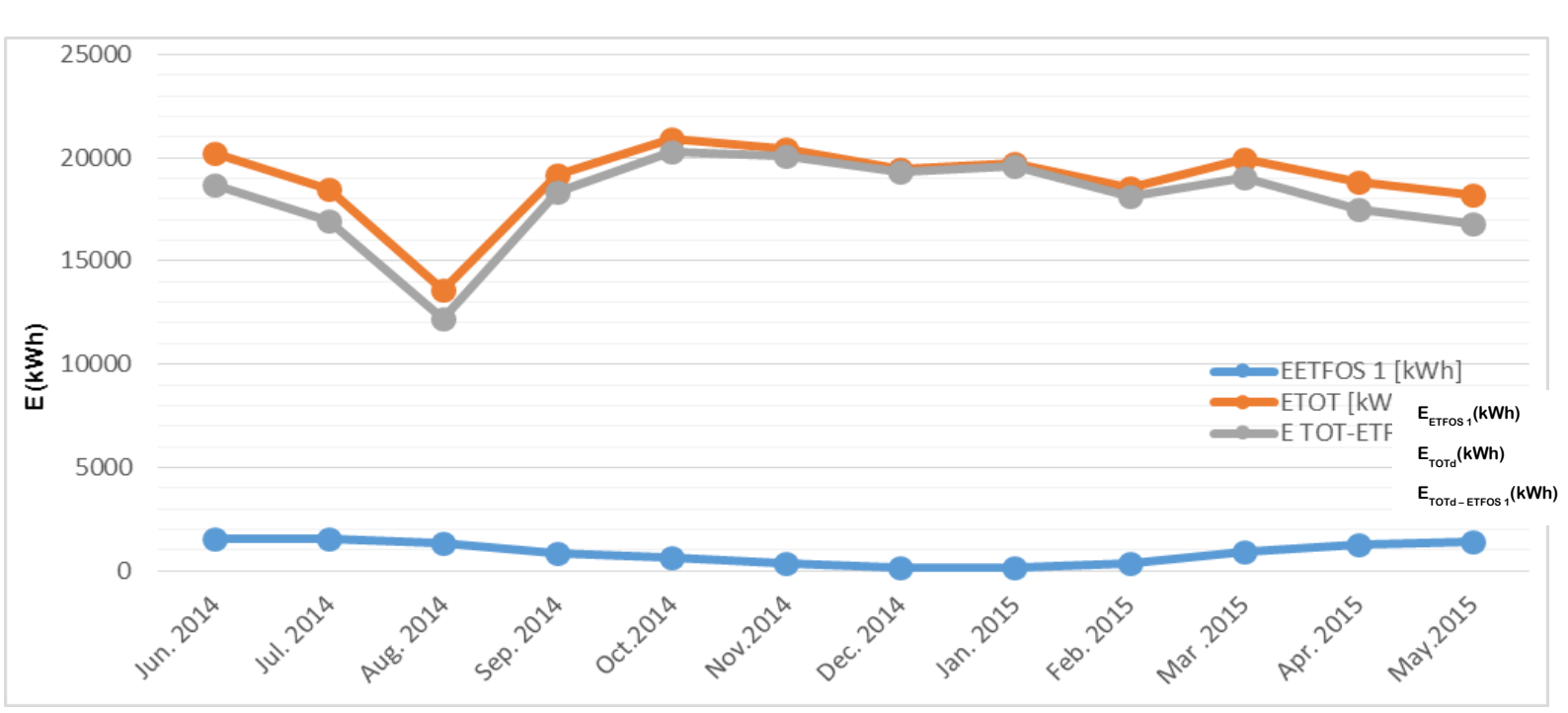

Figure 9 Reducing the load of the building of the Faculty

The total financial income on an annual basis was up to $3.3 \%$ of total consumption. The total financial savings on an annual basis was up to $3.3 \%$ of the total consumption bill. From March 2015 the tariff model of the faculty building changed in a way in which the calculation did not account for the peak power, but the peak power still accounted for the network tariff.

Table 2 Energy cost reduction

\begin{tabular}{cc}
\hline & \multicolumn{1}{c}{ Energy cost reduction } \\
\cline { 2 - 2 } Month & ECR \\
\cline { 2 - 2 } & {$[\mathrm{kn}]$} \\
\hline Jun. 2014 & 1161.74 \\
\hline Jul. 2014 & 1160.33 \\
\hline Aug. 2014 & 1023.06 \\
\hline Sep. 2014 & 632.63 \\
\hline Oct. 2014 & 496.73 \\
\hline Nov.2014 & 250.74 \\
\hline Dec. 2014 & 105.17 \\
\hline Jan. 2015 & 105.94 \\
\hline Feb. 2015 & 281.22 \\
\hline Mar .2015 & 741.33 \\
\hline Apr. 2015 & 1002.75 \\
\hline May 2015 & 1074.40 \\
\hline TOTAL ANNUAL SAVING & $\mathbf{8 0 3 6 . 0 3}$ \\
\hline
\end{tabular}

Table 1 shows the financial savings per month. The calculations account for the electricity bill, network fees, and electricity generated from the photovoltaic $\left(\mathrm{E}_{\mathrm{ETFOS}} 1\right)$. When calculating the savings, the unit price per $\mathrm{kWh}$ for the electricity and network fees are multiplied by the amount of electricity generated from the photovoltaic power plant. Because there is no data on a daily and annual load diagram of the faculty building, the savings do not include allowances for reductions in maximum peak power. Possible further savings can be calculated comparing and analyzing the production and consumption diagrams.

\section{CONCLUSION}

Renewable generation, such as PV, causes an imbalance between electricity production and consumption. Accordingly, new investments are necessary in distribution networks to change their structure from passive to 
active, such as smart grids and microgrids. Almost every researcher has included PV generation as part of the supply side of microgrids. We tested a microgrid model on the Faculty of Electrical Engineering building in Osijek, and this model was also based on a photovoltaic system. We found that the PV power plant produced significant energy savings over a year of measurements.

Because the load diagrams of the faculty building were unavailable, the calculated savings do not include allowances for reductions in the maximum peak power. Possible further savings can be calculated by comparing and analyzing the production and consumption diagrams.

Future research would include installing smart meters for total electricity consumption at the Faculty of Electrical Engineering building, as well as certain loads (air-conditioning system) and energy storage device, then setting up communication between the PV power plant, air-conditioning system, energy storage device, and central control unit. This would produce all necessary measurement data and improve analysis.

\section{References}

[1] Sumper, A.; Baggini, A. 2012: Electrical Energy Efficiency, John Wiley and Sons, Ltd, UK.

[2] Baggini, A. 2008: Handbook of Power Quality, John Wiley and Sons, Ltd, UK.

[3] Pelin, D.; Šljivac, D.; Topić, D.; Varju, V. 2014: Regional Impacts of Different Photovoltaic System, IDResearch Kft / Publikon Kaido, Pecs.

[4] Kroposki, B.; Lasseter, R.; Ise, T.; Morozumi, S.; Papathanassiou, S.; Hatziargyriou, N. 2008: Making Microgrids Work, IEEE Power and Energy Magazine, Artville LLC. DOI: 10.1109/MPE.2008.918718

[5] Liu, X.; Su, B. 2008: Microgrids - An Integration of Renewable Energy Technologies, 2008 China International Conference on Electricity Distribution - CICED 2008. Guangzhou, China.

[6] Katiraei, F.; Iravani, M. R. 2006: Power Management Strategies for a Microgrid With Multiple Distributed Generation Units, IEEE Transactions on Power Systems, Vol. 21, No. 4, November 2006. DOI: 10.1109/TPWRS.2006.879260

[7] Guan, X.; Xu, Z.; Jia, Q.-S.: 2010: Energy-Efficient Buildings Facilitated by Microgrid, IEEE Transactions on Smart Grid, Vol. 1, No. 3, December 2010. DOI: 10.1109/TSG.2010.2083705

[8] Lu, N.; Taylor, T.; Jiang, W.; Correia, J.; Leung, L. R.; Wong, P. C. 2009: The temperature sensitivity of the residential load and commercial building load, 2009 IEEE Power Energy Soc. Gen. Meet., Calgary, AB, Canada, PESGM2009-000775.

[9] Jiang, Z. Rahimi-Eichi, H. 2009 Design, modeling and simulation of a green building energy system, 2009 IEEE Power Energy Soc. Gen. Meet., Calgary, AB, Canada, PESGM2009-000636.

[10] Katz, J. S.; 2008: Educating the smart grid, IEEE Energy2030 Conf., Atlanta, GA, Nov. 17-18, 2008.

[11] O'Neill, R. 2007: Smart grids sound transmission investments, IEEE PowerEnergy Mag., Vol. 5, No. 5, pp. 104-102, Sep.-Oct. 2007.

[12] Lu, Z.; Wang, C.; Min, Y.; Zhou, S.; Lv, J.; Wang, Y. 2007: Overview on microgrid research, Autom. Elect. Power Syst., Vol. 5, No. 19, pp. 100-106, Oct. 2007.

[13] Colson, C. M.; Nehrir, M. H. 2009: A review of challenges to real-time power management of microgrids, 2009 IEEE Power Energy Soc. Gen. Meet., Calgary, AB, Canada, PESGM2009-001250. DOI: 10.1109/PES.2009.5275343

[14] Marnay,C.; Venkataramanan, G.; Stadler, M.; Siddiqui, A.S.; Firestone, R.; Chandran, B. 2008: Optimal Technology Selection and Operation of Commercial-Building Microgrids, IEEE Transactions on Power Systems, Vol. 23, No. 3, August 2008.

[15] Qasem, H. 2013: Effect of Accumulated Dust on the Performance of Photovoltaic Modules, Doctoral Thesis, Loughborough University.

[16] Mertens, K. 2014: Photovoltaics Fundamentals, Technology and Practice, John Wiley \& Sons.

[17] Wekken, T. 2007: Distributed generation \& renewables, Utility Scale Solar Power Plants, Leonardo ENERGY.

[18] Majdandžić, Lj, Fotonaponski sustavi, 2013: Tehnička škola Ruđera Boškovića u Zagrebu.

[19] Tan, Y. T. 2004. Impact on the power system with a large penetration of photovoltaic generation, The University of Manchester Institute of Science and Technology, Department of Electrical Engineering and Electronics.

[20] http://www.solarproductsstore.com/understanding-solar-equipment/what-is-solar-cell/, 2.7.2015. 
[21] Klaić, Z.; Šljivac, D.; Fekete, K.; Kraus, Z. 2014: Load Management Scheme Using Air Conditioning Electric Power Consumption and Photovoltaic Power System Generation, Journal of Energy and Power Engineering, ISSN 1934-8975, Jan. 2010, Volume 4, No. 1 (Serial No. 26), USA. http://dx.doi.org/10.17265/1934-8975/2014.11.013

[22] Udovičić, B. 2005: Elektroenergetski sustavi, Kigen, Zagreb.

[23] Roberts, S.; Guariento, B. 2009: Building integrated photovoltaics/a handbook, Birkhäuser Verlag AG, Basel, Switzerland. 